\title{
RELIGIOUS MODERATION IN THE RECITATION ACTIVITY OF MUSLIMAT NU: An Effort to Prevent Religious Extremism
}

\author{
Yuyun Rohmawati and Ahmad Barizi
}

Universitas Islam Negeri Maulana Malik Ibrahim Malang, Indonesia

E-mail: yuyunrohmawati27@gmail.com

\begin{abstract}
The lives of religious people are often in the spotlight because of complex problems. Religion which is supposed to be the source of peace, causes chaos. Hence, the moderation values must be taught in religious life to create peace. This study aims to explain the efforts and contribution of Muslimat NU Durek Hamlet, Batu City in internalizing the religious moderation values to prevent religious extremism. This is a qualitative research with a case study approach. The data are collected using observation, interviews, and documentation. The analysis technique includes data condensation, data display, conclusion drawing and verifying. The data are then verified using triangulation techniques. The results reveal that there are three efforts done by the Muslimat NU Durek Hamlet to internalize the religious moderation, namely oral method, exemplary, and monitoring. The values taught are balance, tolerance, deliberations, good prejudice and fair. Meanwhile, the contribution of religious moderation in preventing religious extremism is tolerance for differences, being friendly, polite, and doing deliberation.
\end{abstract}

Kehidupan umat beragama sering menjadi sorotan karena masalah yang rumit. Agama yang seharusnya menjadi sumber kedamaian, malah menyebabkan kekacauan. Karena itu, nilai-nilai moderasi harus diajarkan dalam kehidupan beragama untuk menciptakan kedamaian. Penelitian ini bertujuan untuk menjelaskan tentang upaya dan kontribusi Muslimat NU 
Dusun Durek, Kota Batu dalam menginternalisasikan nilai-nilai moderasi beragama dalam pencegahan ekstremisme agama. Studi ini termasuk penelitian kualitatif dengan pendekatan studi kasus. Pengumpulan data menggunakan observasi, wawancara, dan dokumentasi. Teknik analisisnya meliputi kondensasi data, penyajian data, penarikan kesimpulan dan verifikasi. Kemudian data dicek menggunakan teknik triangulasi. Hasil penelitian mengungkapkan bahwaada tiga upaya Muslimat NU Dusun Durek dalam menginternalisasikan nilai-nilai moderasi beragama, yaitu metode lisan, keteladanan, dan monitoring. Nilai-nilai yang diajarkan adalah tawâzun, tasâmuh, shûrâ, husn al-žann, dan 'adâlah. Sedangkan, kontribusi moderasi beragama dalam mencegah ekstremisme agama meliputi toleransi terhadap perbedaan, ramah, tidak kasar, dan bermusyawarah.

Keywords: internalization of values; Muslimat NU; religious moderation; religious extremism

Received: December 08, 2021; Accepted: December 28, 2021

\section{Introduction}

Religious life is contradicting nowadays because of the high tension of Kebebasan Beragama dan Berkeyakinan (KBB, Freedom of Religion and Belief) cases. In March $28^{\text {th }}, 2021$, Indonesian citizen were shocked by a suicide bombing news by a married couple (L and YSF) in front of the Makassar Cathedral Church. The alleged motive is due to revenge for the death of MR (January $\left.6^{\text {th }}, 2021\right)$, who was the couple's mentor (Com 2021). When this action is done in the name of religion, it seems hilarious because there actually is no religion that supports violence.

The Setara Institute released data on $\mathrm{KBB}$ cases during the first administration of President Joko Widodo, in 2014-2020, there were 1.233 incidents and 1.835 actions. The highest spike occurred in 2015 (62 incidents), while the highest increase in actions occurred in 2019 (125 actions). The number of incidents decreased in 2020 by 20 events, but the number of actions soared to 422 actions or increased by 95 . Based on the data, the actors of that incidents are citizens (67 cases) and religious organizations (42 cases) (Institute 2021a; Institute 2021b). Therefore, issues related to freedom of religion and religious moderation are urgently needed.

Religious moderation is an attitude, perspective, and behavior that always takes the middle way, not extreme nor excessive in implementing 
religious teachings (Kementerian Agama 2019b, 2; Nurdin et al. 2019). This attitude makes human not easily emotional, but more harmonious, peaceful, and tolerant. So, religious moderation is not just an option, but a necessity. This may give a good impression. However, the religious moderation attitude is also often debatable because it is considered similar with liberalism. This is absolutely not true. This opinion arises due to the assumption that in religious moderation there are no norms. It is important to know that being moderate in religion does not mean being weak nor has no principle. It is the other way round that being moderate in religion means being confident about the religious teachings they believe in. It is because a religion teaches the principles of fairness and balance, but still shares the truth related to religious interpretation (Kementerian Agama 2019a, 14).

Studying moderation aims to create a moderate society within the diversity of Indonesia. Yaqut Cholil Qoumas, the current Minister of Religious also states in his speech to make religion as an inspiration, not an aspiration. He also emphasized to uphold ukhuwah Islâmiyah (Islamic brotherhood), ukhuwah wataniyyah (nation brotherhood), and ukhuwah bashariyah (human brotherhood), so that peace and unity will be realized (Atmasari 2020).

The discourse of religious moderation is often the main topic in several studies. A research article of Uswatun Hasanah discusses the success of the Prophet Muhammad's da'wah in Mecca and Medina by actualizing religious moderation (Hasanah 2021). Maskuri et al. in his article talks about the ta'lim system and the implemented values to develop the character of religious moderation for the students of Al-Hikam Islamic Boarding School Malang (Maskuri, Ma'arif, and Fanan 2020). Another study discusses the moderate Islamic training program for Aswaja (Ahl al-Sunnah wa al-Jamâ'ah) cadres to equip ustadz/ustadzah (cleric) with moderate Islamic narratives through the ta'lim program (Sajaroh and Mahmudah 2018). These three studies have different focus from the current research article. Although in general, they both discuss religious moderation.

This study examines religious moderation in the recitation (pengajian) activity of Muslimat NU Batu City ( particularly in Durek Hamlet, Giripurno Village, Bumiaji Sub-district, Batu City, East Java, Indonesia), as an effort to maintain harmony. This research is pivotal because it reveals the efforts of Muslimat NU in internalizing the values of religious moderation 
and its contribution to the prevention of extremism religion through recitation, which has not been discussed in previous studies.

Muslimat NU Durek Hamlet is a women's organization that seeks to internalize the values of religious moderation through recitation. What distinguishes it from other organizationsare the geographical location of Durek Hamlet which is quite far from the center of Batu City, the majority of the population works as farmers, the lack of undergraduate, and they hold onto Aswaja understanding. Nevertheless, the community of Durek Hamlet, especially the recitation members, succeeded in realizing harmony in the midst of limitations and differences. This recitation does not have a written draft and SOP (Standard Operating Procedure), but has been able to hold regular recitations since 2019. They have unconsciously implemented religious moderation through the recitation activity of Muslimat NU.

Furthermore, the existence of recitation in this millennial era is also questioned because people prefer narratives in practical studies, which are sometimes more textual. This is the result of the Wahid Foundation survey, that the percentage of Muslims studying religion through television reaches $28,6 \%$. Meanwhile, those who understand religion through recitation in mosques are at 24,5\%, and those through Kiai reach 18,0\% (Hakim 2017, $60)$. Referring to the data, the recitation still has the opportunity to become a forum for learning the values of religious moderation. This is also supported by the research conducted by Hafidz, that it can exist until now because the recitation is not only a medium of $d a^{\prime} w a h$, but also a learning forum. Furthermore, the emotional bond among the recitation congregations (jamaah) is stronger than in other forums because there is no distinction of professions/social strata (Hafidz 2020, 177). These are some of the reasons why researchers are interested in conducting this study.

\section{Method}

This qualitative research was conducted using a case study approach, because it aims to obtain complete and in-depth information, so as to achieve the research focus. The primary data comes from the observations, in-depth interviews, and documentation studies. While the secondary data was from the two books of the Indonesian Ministry of Religion discussing about religious moderation, journal articles, online news/websites, research results, and others. 
The research techniques are observation, in-depth interviews, and documentation studies. The observation indicator used here is the one proposed by Sharan B. Merriam (Suharsaputra 2012, 210). Meanwhile, the selection of informants in interviews was done with purposive sampling technique in hope that they could get data from valid informants. Interviews were conducted with the Chairperson of the Muslimat NU of Batu City, the Founder of the recitation of Muslimat NU, the Chairperson of the recitation of Muslimat NU Durek Hamlet, the administrators, and several members.

The data are then analyzed using the techniques proposed by Miles, Huberman, and Saldana, which include the stages of data condensation, data display, conclusion drawing and verifying (Miles, Huberman, and Saldana 2020, 34-35). Furthermore, the data is validated through the triangulation technique according to Norman K. Denkin (Arifin 2011, 164).

\section{A Glimpse of the Recitation of Muslimat NU Durek Hamlet, Batu City}

The establishment history of the Muslimat NU recitation in the Durek Hamlet, Giripurno Village, Bumiaji District, Batu City has never been written/recorded. Therefore, the researchers conducted interviews with the founder of the recitation, Ustadz Ahmad Nuril Mustafa. He said, that was the result of the initiation of several women who wanted to study religious knowledge, but at that time no forum had been formed.

One of them, Ms. Hj. Mitun (Ustadz Ahmad Nuril Mustafa's mother), explained the establishment process. She previously had congregation in tahlîl (usually an activity of praying for the deceased) activities and had been a member of Muslimat NU. She then invited her fellow members to establish a recitation forum. She told that intention to Ustadz Nuril, and he also welcomed the request. Considering the condition, most of the Durek Hamlet women have a fairly minimal background in religious knowledge, education, the majority of their professions are farmers, and living in rural areas. These are some of the things that have prompted the immediate establishment of a recitation forum, besides the anxiety experienced by female elders when talking to Ustadz Nuril at his home at that time.

Prior to the establishment of the recitation forum, Ustadz Nuril first held discussions with the mosque takmir (manager), mushallah takmir, ustadz, and also the branch management of NU on how to establish a 
recitation forum. In short, all of them accepted and supported the initiation. Furthermore, they were also willing to take turns being the speakers in the recitation activities. In short, the Branch Committee of Muslimat NU formed and inaugurated the recitation to be the place in studying religious sciences, such as: sharia, figh, Sufism, morality, Aswaja, and even nationality, which is now echoed with religious moderation. This forum was officially formed by Ustadz Nuril on Wednesday, April 17, 2019 (Mustafa, interview 2021).

\section{Understanding the Vision and Mission of the Muslimat NU Durek Hamlet, Batu City}

The vision of Muslimat NU, as stated in the Statutes and Bylaws (AD ART) Muslimat NU Chapter IV Article 4 is "The realization of a prosperous society whose souls are filled with the teachings of Islam Ahl al-Sunnah wa alJamâ'ah (Aswaja) in the Republic of Indonesia (NKRI), which is prosperous and fair, that is blessed by Allah Swt". Meanwhile, the vision of the recitation activity is "The realization of the community (especially Durek Hamlet's women) who are aware and understand about religious knowledge properly and correctly, and enforce it in everyday life".

Meanwhile, the missions are (a) realizing the Indonesian people, especially women, who are aware of religion, society, nation and state; (b) realizing Indonesian society, especially women, who are qualified, independent and devoted to Allah Swt.; (c) realizing Indonesian society, especially women, who are aware of their obligations and rights according to Islamic teachings, both as individuals and as members of society; and (d) implementing the goals of Jam'iyyah NU so there will be a fair and prosperous society that is equitable and blessed by Allah Swt.

The recitation forum of Muslimat NU also has several missions: (a) creating high-quality, independent and devoted women to Allah Swt.; (b) creating women who understand religious knowledge properly and correctly; (c) realizing women who are steadfast in religious teachings, but remain tolerant of permissible lines; and (d) realizing women who are able to balance religious and world life.

\section{Efforts to Internalize Religious Moderation Values}

In the Big Indonesian Dictionary (KBBI), moderation has two meanings, reducing violence and avoiding extremes. Whereas in English, moderation means 'average, core, standard or impartial' (Kementerian 
Agama 2019a, 15). In Arabic, it is known as wasatiyyah (Fahri and Zainuri 2019, 96). The term wasatiyyah is derived from the word wastu, which means 'fair, good, and middle' (Rahman 2020,9).

Etymologically, the meaning of wasatiyyah according to Ibn 'Ashûr is Islamic values that built on the basis of a straight, middle mindset, and not excessive in everything (Fauzan 2019, 34). So, when moderation is associated with religious discourse, it can be understood as an attitude, perspective, and behavior that always takes the middle, fair and not extreme way in religion (Kementerian Agama 2019b, 2).

Today, social life (including in religion) cannot be separated from diversity. This should be given much attention in order to create a peaceful, harmonious, and non-extreme environment. This problem can be resolved by upholding the basic principles of religious moderation, that are fair and balanced (Kementerian Agama 2019a, 19). The same thing was also done by the Muslimat NU of Batu City (including the Durek Hamlet's Muslimat $\mathrm{NU}$ ), that is internalizing the values of religious moderation through recitation. As said by the Head of Branch (PC) of Muslimat NU Batu City:

"...we have just started the mission from the Ministry of Religion of the Republic of Indonesia to spread moderate attitudes, understandings, and behaviors in religion... we are also still learning through meetings, webinars, and other discussions that specifically discuss religious moderation. Before that, we will convey it to Muslimat NU down to the lower level, namely the sub-branches. This is done through recitation activities Miss, which are shaded by the HIDMAT MNU (Da'wah Group and NU Muslimat Ta'lim Council)...." (Astutik 2021).

Based on these explanations, it can be understood that the material for religious moderation in the Muslimat NU of Batu City is still relatively new. However, the material has been presented in the Muslimat NU ta'lim. In this case, there are no specifications regarding the material design, schedule, method, and delivery strategy. So, for now, they just follow the flow, it means that religious moderation material is delivered at every meeting and in any discussion. This is as explained by Ustadz Ahmad Nuril Mustafa: "...We insert religious moderation material in every discussion..." (Mustafa, interview 2021).

Regular recitation is conducted by Muslimat NU Durek Hamlet every Friday at $04.00 \mathrm{PM}$. There usually is a process of internalizing the values of religious moderation within the forum. Internalization is a suitable strategy 
in growing and developing a value to become a character. This is in line with the definition of internalization proposed by Sigmund Freud and Scott. According to Sigmund Freud, internalization is the unification/amalgamation of attitudes, standards of behavior and character that exists within a person. Meanwhile, according to Scott, internalization starts by involving ideas/concepts of an external personality, then moving from another individual personality. It is then accepted and believed to be seen in real action (Nabila 2021, 23).

During the research, we found three efforts to internalize the values of religious moderation in the recitation of Muslimat NU Durek Hamlet. They are through the methods of explanation, example, and monitoring.

The method of explanation is the first stage in internalizing the values of religious moderation through recitation. In this stage, they use oral explanation (Munir and Ilaihi 2006, 32-33). It is to provide an understanding of the meaning and concepts related to values that will be internalized to the congregation/person. The example is seen in the recitation that was held on September 10, 2021, with Ustadz Umar Ba'I as the speaker. In particular, he discussed ma'rifat (know God closer) to Allah. $\mathrm{He}$ also discussed the notion of religious moderation; that we should choose mediocrity, tolerance, and moderation when being mocked. The following is the explanation of Ustadz Umar Ba'i:

"Simply, moderation is neither excessive nor lacking in any way. For example, we are NU, but we shouldn't justify our beliefs too much in front of people with different beliefs. Especially when it comes to blaming religion. This is not good, so we should be able to respect each other" (Ba'i 2021).

The explanation shows that there are values of moderation and tolerance described in the recitation. Tolerance is a moderate attitude that tends to respect all aspects of life (Mussafa 2018, 34). These values must be internalized as one of the characteristics of religious moderation.

The application of this method can also be seen in the next recitation, which was on September 17, 2021. The material for the recitation was delivered by Ustadz Ahmad Nuril Mustafa who discussed the characteristics of the Prophet Muhammad PBUH. and the period of the Prophet's da'wah. The holy book used is Diba'. From this theme, it does not specifically discuss about religious moderation, but it is discussed as follows: 
"The Prophet never complained in da'wah if the enemy is also silent and doesn't respond to him... since Islam is a religion that loves peace and friendly, then we shouldn't get angry easily/even fight."

".......so you can pray without wearing a mukenah [prayer clothes]. But the important thing is to cover the nakedness (awrat). So in this case, the most important thing is to be able to be critical in religion. It is not easy to blame, but we should try to be more tolerant..." (Mustafa, observation 2021).

From the two quotes, it can be understood that the values of religious moderation are really explained, although only briefly. Next, the study discusses five things that can be done in a hurry. This material was delivered by Ustadz Ikhwanul Muslimin and the holy book used was Durrat al-Nâsihîn. The following is an explanation of the material on religious moderation that he conveyed:

"The fifth thing is to provide treats/welcome guests. Is that clear, ma'am?... If there are non-Muslim guests, sShould we just accept/expel? Yes, don't expel them, but we must accept them well too. Especially if he or she has good intentions, for example, they want to establish friendship. So, in this case, we must have a tolerant attitude, good prejudice, and continue to do good with anyone" (Muslimin 2021).

From this it can be understood that the value of religious moderation described is the value of tolerance, good prejudice, and doing good. Good prejudice is the key to be tolerance. That is also a suggestion from Allah Swt.: "Truth comes from your Lord, so do not be among those who doubt it" (Q.S. al-Baqarah [2]: 147) (Arif 2020, 41).

In the next recitation, material about the priority (fadîlah) of wearing a turban and the priority of fasting was delivered by Ustadz Sunario, who used the Bâb al-Hadith holy book. In the middle of his explanation, he also conveyed moderation, as follows:

"Wearing a turban is good, especially when the Friday prayer. Two rak'ahs is better than the prayer of seventy people...even so we should not force others to do it" (Sunario 2021).

This explanation further strengthens that the internalized value is tolerance. It is the povital character that must be possessed to be moderate in religion.

In the last study, the recitation material was delivered by Ustadz Hamzah, who discussed the pros and cons of commemorating the birthday of the Prophet Muhammad PBUH: 
“... some people argue to not celebrate the birthday of the Prophet Muhammad PBUH... why did they refuse? It is okay. That's their right. We don't blame them either. We just take the middle way, which is respecting differences" (Hamzah 2021).

Thus, the value to be internalized through the explanation method is the attitude of tawassut (middle way). It means to not be ifrât (excessive in religion) and tafrît (reducing religious teachings) (Amin 2019, 17).

As explained above, efforts to internalize the values of religious moderation are carried out using the explanation method. This is in line with the first stage of value internalization proposed by Muhaimin, that is the transformation stage. According to him, the value transformation is a process to inform the existence of good and bad values, which is carried out by means of verbal communication between the giver and the recipient (Idris 2017, 34).

The second effort to internalize the values of religious moderation in the recitation of Muslimat NU Durek Hamlet is by exemplary method. It is seen in a discussion/questioning situation. In this case, the ustadz always tries to appreciate every question and answer/criticism/suggestion from all participants. This can also encourage them to understand the importance of deliberation. It is not easy to decide a case unilaterally, especially for the benefits of certain person. This is what distinguishes the recitation from other forums, that there is no grouping of positions/social strata. So, the study can exist until now (Hafidz 2020, 177).

Furthermore, the exemplary method is done by giving examples. For example, when the Prophet Muhammad PBUH. carried out da'wah, then got insulted from the Quraish infidels, instead of being angry, he chose to keep silent/not replying. This is done to encourage the congregation so that it is not easy to be rude. Furthermore, through the exemplary method, the values of fairness, balance and good prejudice are also internalized. The value of justice is exemplified by explaining the work of the congregation, most of whom are vegetable farmers, so in this case they are reminded to always be fair in giving the scales. Fair is an attitude that is highly recommended by Allah Swt. through His word: "And uphold the scales with justice and do not reduce the balance" (QS. al-Rahmân [55]: 9).

Furthermore, balanced values are internalized by providing an example through the story of the Prophet as a Messenger of God and also the head of government, as well as being active as a very honest trader. This 
definitely can prove that the Prophet also minded the affairs of the hereafter and also the world. The internalization of positive thinking values is done by providing a discussion regarding the pros and cons of commemorating the birthday of the Prophet Muhammad PBUH. In this case, the ustadz reminded the congregation to always be positive thinking with anyone, especially those who have a solid foundation to serve as a guide.

The choice of this exemplary method is in line with the recitation method described in the Quran, "There has certainly been for you in the Messenger of Allah an excellent pattern for anyone whose hope is in Allah and the Last Day and [who] remembers Allah often." (Q.S. al-Ahzâb [33]: 21). In the verse it is clear that through giving a good example, a person will tend to appear good character and personality, and vice versa.

Furthermore, when the exemplary method is analyzed using the value of internalization stage, it is in line with the transaction stage. According to Muhaimin, transaction value is a process that involves two-way communication and is reciprocal (Idris 2017, 34). In addition, this method is also in line with the one in POAM NU, namely the bil haal method (example/exemplary) (NU n.d., 125).

The monitoring method is the last effort in internalizing the values of religious moderation through recitation activities. This is very important to do, because it relates to the recitation element, namely athar (recitation effect). Athar is a feedback from recitation activities (Munir and Ilaihi 2006, 35), so it can be seen whether the internalization process works or not in the recitation of Muslimat NU.

In this method, the ustadz makes an internalization effort by asking whether the members have been implemented the lesson they got or not. In addition, the ustadz also tries to always pay attention to the development of behavior shown by the congregation, whether it is during or outside the recitation. This way, it can strengthen the congregation's answers.

The analysis of this monitoring method is in line with the third stage of internalization value proposed by Muhaimin in the Idris's book, it is called trans-internalization value. According to him, internalization is a deeper process than transactions because it involves mental and personality communication, in addition to verbal communication (Idris 2017, 35). In this case, it can be seen by the changes in the attitudes, views, and actions of the congregation, which are applied in everyday life. 


\section{Religious Moderation: A Point of Effort to Prevent Religious Extremism}

Religious extremism is one of the most crucial problems, which arises due to excessive religious motivation (there is a tendency towards one side) (Pratt 2017, 1). This is the happening reality in the world, including Indonesia which has a variety of cultures, languages, races, ethnicities, and religions. This absolutely must be faced properly to create peace and harmony in life. This is an important note for the Ministry of Religion of the Republic of Indonesia in particular, so a discourse of religious moderation eventually becomes the focus.

Religious moderation is understood as a strategy that must be applied in religious life because two principles are upheld, namely fairness and balance. It also encourages the attitude of tolerance. Moreover, this is what should be done to restore the essence of religious practice, that is to maintain human dignity as God's noble creatures and protect human life (Kementerian Agama 2019a, 8). In addition, normatively religion strongly supports the values of peace and harmony, even in terms of challenges and contestations (Pratt 2017, 5; Suradi et al. 2021).

Starting from the importance of religious moderation and the dangers posed by religious extremism, creating moderate attitudes, views, and actions are very important. This can be done by internalizing the values of religious moderation, as has been done by Muslimat NU Durek Hamlet through recitation activities. That way, they can contribute (more or less) to prevent the emergence of religious extremism. Considering that $99 \%$ of the religion of Durek Hamlet is dominated by Islam (particularly NU).

One of the contributions is to make the congregation of Muslimat NU Durek Hamlet have a tolerant attitude, especially in religion. This can be shown by the attitude of the congregation who tend to appreciate and accept different opinion, for example regarding the commemoration of the Prophet Muhammad's birthday (Maulud Nabi). They even do not feel bothered to have non-Muslim neighbors. Here is one response from the congregation:

"It's alright if they don't want to celebrate the Prophet's birthday, but if we believe it, that is also good. Yes let's do it. But Yyou don't have to force other people to do similar Moreover, Islam is a religion that loves peace" (Lilis 2021).

The statement above shows that the congregation has a tolerant view of differences. 
The form of tolerance that the congregation showed was also seen when the researchers attended the recitation for the first time. They gave a very friendly and open welcome, even though we have never known each other. Thus, it proves that they do not have negative thoughts (especially related to creed/religion or others) towards other people. In addition, when the researchers attended the congregational maghrib prayer, who only wore a top mukenah and socks, but there were no congregants who reprimanded or took a negative view of the researcher. Their attitude is even more friendly in every meeting.

Furthermore, they put a lot of emphasis on deliberation in making decisions. During the research, they held deliberations regarding tahlîl activities that might change in time and deliberation on the concept of commemorating the Prophet Muhammad's birthday. No party dominates because every congregation has the same rights in voicing their opinions.

Some of the attitudes, views and actions above show that the members of the recitation of Muslimat NU are moderate and anti-extremism. Especially when analyzed with the characteristics of religious extremism according to Yûsuf al-Qardawî, there is no indication that they can fall into the mentioned category. The characteristics are (1) tend to be fanatical about personal opinions and do not want to accept others' opinions; (2) forcing others to do something that is not commanded by Allah Swt., for example, not accepting rukhşah (relief in worship when in trouble); (3) tend to burden oneself disproportionately, for example, forcing people who have just converted to Islam with a lot of worship; (4) tend to be harsh and rude; (5) having negative thoughts/prejudice towards other people; (6) describing the general public in the most ideal figure, meaning always trying to be in a state of purity from sin (even though it is impossible/beyond imagination) (Halim 2015, 10-24).

Furthermore, religious moderation is indeed the right strategy/religious concept applied in diverse lives. It is because moderation does not justify the existence of radical thoughts. It also does not ignore the content of the Quran and hadith as the main legal basis for Muslims, so that, it will reflect a more tolerant and not tenuous attitude in interpreting the teachings of Islam. In addition, it can also provide a broader understanding of Islamic teachings which consists of two aspects, that are aqeedah (belief) and social aspects (mu'âmalah) (Dodego and Witro 2020, 204). 


\section{Conclusion}

All in all, the Muslimat NU Durek Hamlet does not yet have written standards or special rules in conducting recitation activities. For example, there is no particular media, method, materials, and holy books used. It is done depending on the readiness of the ustadz (as a main speaker). Nevertheless, the recitation has been running well and routinely until now. From their recitation activities, they indirectly found a mostly-used method, namely verbal/explanation, exemplary, and monitoring. Through these three methods, the values of religious moderation are embedded and manifested in the daily lives of the congregation. The internalized values include: tawâzun (balanced), tasâmuh (tolerance), shûrâ (deliberation), h̆usn al-zann (good prejudice), and 'adâlah (fair). All of these are able to contribute to the prevention of religious extremism in the community of Muslimat NU Durek Hamlet. As the attitude shown, they tend to be more tolerant of differences, friendly, polite, and prioritizing deliberation in making every decision.

\section{References}

Amin, Kamaruddin. 2019. Pedoman Implementasi Moderasi Beragama Dalam Pendidikan Islam. Indonesia: Keputusan Direktur Jenderal Pendidikan Islam.

Arif, Mahmud. 2020. Moderasi Islam dan Kebebasan Beragama Perspektif Mohamed Yatim $\mathcal{E}$ Thaha Jabir Al-Alwani. 1st ed. Yogyakarta: Deepublish.

Arifin, Zainal. 2011. Penelitian Pendidikan. 1st ed. Bandung: PT. Remaja Rosdakarya.

Atmasari, Nina. 2020. "Ini Isi Pidato Pertama Gus Yaqut Setelah Menjabat

Menteri Agama." Harian Jogja.

https://news.harianjogja.com/read/2020/12/23/500/1058757/iniisi-pidato-pertama-gus-yaqut-setelah-menjabat-menteri-agama (January 14, 2021).

Com, Tim Detik. 2021. "Dugaan Motif Balas Dendam Di Balik Aksi Bom Bunuh Diri Makasar.” Detik News. https://news.detik.com/berita/d5519360/dugaan-motif-balas-dendam-di-balik-aksi-bom-bunuh-dirimakassar/2 (April 9, 2021). 
Dodego, Subhan Hi Ali, and Doli Witro. 2020. "The Islamic Moderation and The Prevention of Radicalism and Religious Extremism in Indonesia." Dialog 43(2): 199-208.

DOI: https://doi.org/10.47655/dialog.v43i2.375.

Hafidz, Muh. 2020. "Majlis Ta'lim: Institution for Strengthening Islamic Moderation." Journal of Nahdlatul Ulama Studies 1(2): 162-80.

DOI: https://doi.org/10.35672/jnus.v1i2.162-180.

Fahri, Mohamad, and Ahmad Zainuri. 2019. "Moderasi Beragama di Indonesia." Intizar 25(2): 95-100.

DOI: https://doi.org/10.19109/intizar.v25i2.5640.

Fauzan, Fauzan. 2019. Module for Islamic Religious Education Teacher (Islam and Religious Moderation). ed. Halili and Ikhsan Yosarie. Jakarta: Pustaka Masyarakat Setara.

Hakim, Muhammad Aziz. 2017. Moderasi Islam: Deradikalisasi, Deideologisasi dan Kontribusi Untuk NKRI. 1st ed. ed. Saiful Mustofa. Tulungagung: IAIN Tulungagung Press.

Halim, Amanullah. 2015. Buku Putih Kaum Jihadis: Menangkal Ekstremisme Agama dan Fenomena Pengkafiran. 1st ed. ed. Faiq Ihsan Anshori. Tangerang: Lentera Hati.

Hasanah, Uswatun. 2021. "Dakwah in the Study of Religious Moderation." Alfuad: Jurnal Ilmiah Sosial Keagamaan 5(1): 59-72.

DOI: http://dx.doi.org/10.31958/jsk.v5i1.3188.

Idris, Saifullah. 2017. Darussalam Publishing Internalisasi Nilai Dalam Pendidikan (Konsep dan Kerangka Pembelajaran Dalam Pendidikan Islam). 1st ed. ed. Susanto. Yogyakarta: FTK Ar-Raniry Press.

Institute, Setara. 2021a. "Memahami Situasi Intoleransi." Setara Institute. https://setara-institute.org/memahami-situasi-intoleransi/ (April 6, 2021).

Institute, Setara. 2021b. "Pandemi Lahan Subur Diskriminasi dan Intoleransi." Setara Institute. https://setara-institute.org/pandemilahan-subur-diskriminasi-dan-intoleransi/ (April 9, 2021).

Kementerian Agama. 2019a. Moderasi Beragama. 1st ed. Jakarta: Badan Litbang dan Diklat Kementerian Agama RI. 
Kementerian Agama. 2019b. Tanya Jawab Moderasi Beragama. 1st ed. Jakarta: Kementerian Agama RI.

http://library1.nida.ac.th/termpaper6/sd/2554/19755.pdf.

Maskuri, A. Samsul Ma'arif, and M. Athoiful Fanan. 2020. "Mengembangkan Moderasi Beragama Mahasantri Melalui Ta'lim Ma'hadi di Pesantren Mahasiswa." J-PAI 7(1): 32-45.

DOI: https://doi.org/10.18860/jpai.v7i1.11239.

Miles, Matthew B., A. Michael Huberman, and Johnny Saldana. 2020. Qualitative Data Analysis (A Methods Sourcebook). 4th ed. ed. Helen Salmon. India: SAGE Publications.

Munir, Muhammad, and Wahyu Ilaihi. 2006. Manajemen Dakwah. 1st ed. Jakarta: Kencana.

Mussafa, Rizal Ahyar. 2018. "Konsep Nilai-Nilai Moderasi Dalam Al-Qur'an dan Implementasinya Dalam Pendidikan Agama Islam (Analisis AlQur'an Surat Al-Baqarah 143)." Undergraduate Thesis. Universitas Islam Negeri Walisongo Semarang.

Nabila, Nur Silva. 2021. "Internalisasi Nilai Islam Moderat Dalam Pembelajaran Pendidikan Agama Islam Di Lembaga Pendidikan NU dan Muhammadiyah (Studi di SMA Daruttaqwa dan SMA Muhammadiyah 1 Gresik).” Masters Thesis. Pascasarjana Universitas Islam Negeri Sunan Ampel Surabaya. http://digilib.uinsby.ac.id/50171/2/Nur Silva Nabila_F02318101.pdf.

NU, Muslimat. Pedoman Organisasi Administrasi Muslimat NU. Batu.

Nurdin, Ahmad Ali, Rosihon Anwar, Husnul Qodim, and Usep Dedi Rustandi. 2019. "The Role of Centre for Islamic Thought and Education (CITE): Correcting Negative Image of Islam, Spreading Moderate Islam in Australia." Ulul Albab: Jurnal Studi Islam 20(1): 147-76.

DOI: https://doi.org/10.18860/ua.v20i1.5589.

Pratt, Douglas. 2017. Religion and Extremism: Rejecting Diversity. 1st ed. New York: Bloomsbury Academic.

Rahman, Samson. 2020. Wasathiyah Dalam Al-Qur'an (Nilai-Nilai Moderasi Islam Dalam Akidah, Syariat dan Akhlak). 1st ed. ed. Artawijaya. Jakarta: 
Pustaka al-Kautsar.

Sajaroh, Wiwi Siti, and Sarah Hajar Mahmudah. 2018. "NU Women's Role in Narrating The Moderate Islam Through Majelis Taklim.” Atlantis Press 129.

Suharsaputra, Uhar. 2012. Metode Penelitian. Bandung: PT. Refika Aditama.

Suradi, Ahmad, Qolbi Khoiri, Nilawati Nilawati, Nopian Gustari. 2021. "Designing the Pesantren Curriculum to Counter Radicalism: Study on Pondok Pesantren Wali Songo Ngabar Ponorogo." Ulul Albab: Jurnal Studi Islam 22(1): 49-68.

DOI: https://doi.org/10.18860/ua.v22i1.11212.

Interview with Ahmad Nuril Mustafa, Durek, September 10 ${ }^{\text {th }}, 2021$.

Interview with Gini Astutik, Batu, October 02 ${ }^{\text {th }}, 2021$.

Observation with Ahmad Nuril Mustafa, Durek, September 17 $7^{\text {th }}, 2021$.

Observation with Hamzah, Durek, October 15 $5^{\text {th }}, 2021$.

Observation with Ikhwanul Muslimin, Durek, October 01 ${ }^{\text {th }}, 2021$.

Observation with Sunario, Durek, October 08 ${ }^{\text {th }}, 2021$.

Observation with Umar Ba'i, Durek, September 10 2021. 